American Journal of Environmental Sciences 7 (2): 161-165, 2011

ISSN 1553-345X

(C) 2010 Science Publications

\title{
Green Building Construction Thermal Isolation Materials (Rockwool)
}

\author{
Mahmoud Itewi \\ Department Civil Engineering, Faculty of Engineering, \\ Tafila Technical University, 66110, Tafila, Jordan
}

\begin{abstract}
Problem statement: Building insulation consisting roughly to anything in a structure that is utilizes as insulation for any reason. Thermal insulation in structures is a significant feature to attaining thermal comfort for its tenants. Approach: Insulation decreases unnecessary warmth loss or gain and can reduce the power burdens of heating and cooling structures. It does not automatically having anything to do with problems of sufficient exposure to air and might or might not influence the amount of sound insulation. Results: In a constricted way insulation can just mean the insulation substance used to reduce heat loss, such as: Glass wool, cellulose, polystyrene, rock wool, urethane foam, vermiculite and the earth, but it can also entail a variety of plans and methods used to deal with the chief forms of heat movement like transmission, emission and convection substances. The efficiency of insulation is normally assessed by its R-value. However, an R-value does not allow for the superiority of assembly or narrow green issues for each structure. Building superiority matters comprise insufficient vapor obstructions and troubles with draft-proofing. Additionally, the property and concentration of the insulation substance itself is vital. Fiberglass insulation materials, for example, made out of short fibers of glass covered on top of each other is not as long-lasting as insulation prepared from extended entwined fibers of glass. Conclusion/Recommendations: Rockwool insulation is a kind of insulation that is constructed out of real rocks and minerals. It furthermore is known by the names of mineral wool insulation, stone wool insulation or slag wool insulation. A broad collection of goods can be constructed from Rockwool, because of its outstanding capability to obstruct sound and heat. Rockwool insulation is normally utilized in building assembly, manufacturing plants and in automotive purposes. In this study i proposed to use Rockwool as a good insulation material to use for insulate the outside walls, this proposal proved by advance calculation and applied to exterminate case in Jordan because this material is available in Jordan.
\end{abstract}

Key words: Insulation materials, R-value, green building, thermal conductivity, magnetic field, rockwool insulation, K-factor, global warming, Synthetic Vitreous Fibers (SVFs)

\section{INTRODUCTION}

In order to produce Rockwool insulation, mineral deposits and other unprocessed materials are warmed to about $2910^{\circ} \mathrm{F}$ (about $1600^{\circ} \mathrm{C}$ ) in a heating system, during which a stream of air or steam is blown. Additionally sophisticated manufacturing methods are based on turning the melted rock at high momentums in a spinning wheel, just like the way that cotton candy is prepared. The completed result is a heap of very fine entwined fibers, bound collectively with starch. Oil is also added throughout fabrication in order to reduce the development of dust.

Each strand of Rockwool insulation is a superior conductor of warmth on their own, but rolls and sheets of this insulation are extremely proficient at stopping heat movement. They are frequently utilized in order to stop the progression of fire within structures, because of their tremendously elevated melting point. Just like with other types of insulation, Rockwool can contribute to the large role of dropping energy usage in homes and businesses. Because it is prepared of natural resources, Rockwool insulation is secure to produce and use, when appropriate rules are used. Many years of investigation have revealed that it causes little to no wellbeing dangers to people, comprising that of respiratory and other cancers (Kudo et al., 2009).

While it is not striking to rodents, Rockwool can cause troubles in other means, particularly if permitted to become damp. Rockwool insulation is capable of keeping a great quantity of water, even though gravity will cause it to gradually drain out, as long as it has a method to escape. This capacity to retain water, together with the reality that it holds a definite quantity of air at all times, has made Rockwool a popular medium in horticulture and hydroponics. These characteristics of Rockwool permit for superior root growth and nutrient absorption. It also supplies a high- 
Am. J. Environ. Sci., 7 (2): 161-165, 2011

quality mechanical arrangement for the plant, keeping it strapping and steady. In its normal state, Rockwool has a fairly high $\mathrm{pH}$, which is obstructive of plant expansion. In order for it to be an appropriate as a means for growing plants, it must be cared for to lower the $\mathrm{pH}$ to a more even and neutral value that will permit the plant to flourish. This care entails drenching the Rockwool in $\mathrm{pH}$-adjusted water for at least a twenty four period prior to use (Rockwool Firesafe Insulation) Fisk and Rosenfeld (1998).

Rockwool makes available a multiplicity of advantages, including fire resistance and sound absorbency. Due to the fact that the fibers will not blow up and have a tremendous dissolving point which is above 2,150 degrees F, Rockwool insulation works well as a fire barricade. Its fire resistant characteristics holdup the spread of fire, which could add valuable minutes needed for escape. Rockwool insulation also deters water, rot, mildew and mold, including a variety of types of bacterial growths. Because it wards off water, rock wool will never deteriorate or droop. The content of Rockwool is thick, so it diminishes air flow and sound wave transmissions (Rock Wool Insulation).

Rockwool insulation decreases energy costs and necessities in residential houses, office spaces and production plants. It has been reported that Rockwool insulation can decrease residential energy costs by at least forty percent. These energy savings are not just helpful on the money, but also for the environment, as the reliance on energy goes down. Rockwool insulation saves 128 times more energy than is necessary for manufacture, transport and removal when properly put Straube (2007).

The things made with Rockwool insulation have outstanding sound absorption capabilities which prevent unwanted noise pollution. This is done by controlling it either at the foundation, along the path from the foundation to the receiver or at the receiver's end. Rockwool is great at dampening noise. One should use thick Rockwool, at least $30 \mathrm{~mm}$ thick, spaced at least 4 inches in order to get the best use. Rockwool can also be used to diminish the sound inside a room when placed a few inches away from the walls or hung on wooden spacers. Rockwool can also be used to line, fill and coat walls, the door and under the floor (FAQs about Mineral Wool (Rock and Slag Wool) Insulation, 2005).

Some asbestos alternatives, including Rockwool fibers, resemble asbestos structurally and their probable harmful consequences on humans have been a fear. Pulmonary fibrosis has taken place in experiments on rats that have been exposed to Rockwool, but no progress of lung tumors was observed. In regards to the safety of Rockwool, the International Agency for Research on Cancer (IARC) currently categorizes
Rockwool Group 3: limited confirmation in experimental animals for the carcinogenicity and insufficient evidence in humans for the carcinogenicity (Fisk and Rosenfeld, 1998).

The first grade of insulation, which is often about $30-50 \mathrm{~mm}$, is focused on the avoidance of harm to people who are operating or working close to the installations. The second grade of insulation, an economical thickness which is often more than 100 $\mathrm{mm}$, is focused on momentous heat loss reduction and thus attaining a better return on investment. The third grade of insulation, an ecological thickness which is typically about $40 \%$ thicker than the economical thickness, is focused on dropping heat loss to almost nothing and shielding the environment (Rodman and Lenssen, 1995).

Lung magnetometry was initially performed by Cohen in 1973. The main feature of this technique is that it is an in vivo test of the living organism and the appropriate function of the central defense cell in the lung (macrophages) can be non-invasively observed. Using this technique, knowledge can be attained about the intracellular progress of alveolar macrophages, subsequent to making them to consume magnetic particles, by evaluating the remanent magnetic field force in the lung after outside magnetization. Because the ingested magnetic particles continue to say put in the phagosomes, intracellular progress of the phagosomes can be noticed by measurement of remnant magnetic field (Rockwool Firesafe Insulation).

Currently, the cytotoxicity of chrysotile, which is a type of asbestos, as well as Rockwool along with other Man-Made Vitreous Fibers (MMVFs) have been evaluated by cell magnetometry. This method established cytoskeleton-dependent functions of macrophages, which contribute to a significant role in phagocytosis and is used to assess the degree of harm caused on macrophages.

Biological consequences of MMVFs have to be looked at not only at the cell level but also in the lung. To date there have been no studies done to look at the safety of Rockwool by way of lung magnetometry. In a study done by Kudo et al. (2009), rats were forced to inhale Rockwood a nose-only inhalation exposure system and then looked at by lung magnetometry, a biopersistence test and pathological examination. The wellbeing features and safe utilization of mineral wools have been looked at for almost seventy years. NAIMA and its associate businesses have put forth tens of millions of dollars in investigative projects being done by important independent laboratories and universities in the United States and around the world in order to examine the possibility of human wellbeing influences 
Am. J. Environ. Sci., 7 (2): 161-165, 2011

of rock and slag wool as well as other Synthetic Vitreous Fibers (SVFs), like fiber glass.

\section{MATERIALS AND METHODS}

Rockwool insulation comes in many different forms and can be used to produce many different products and we take the types as shown in Table 1 and there values of density and K-value results as shown in Table 2.

R-Value: The National Commercial and Industrial Insulation Standards Manual defines R-Value as "A measure of the ability to retard heat flow rather than to transmit heat". The higher the R-Value the higher (better) the insulation value.

Determining the R-Value for flat insulation. simply divide the thickness of the insulation by it's K-factor.

Thermal conductivity (K-factor) is the major of a materials ability to transfer heat. Materials which transfer heat readily have high K-factors. On the other hand, substances that do not transfer heat readily (poor conductors') have low K-factors and are classified as insulators such as elastomeric or polyolefin flexible closed cell foam insulations:

$$
\mathrm{K}-\text { Value }\left(\mathrm{W} / \mathrm{M} .{ }^{\circ} \mathrm{C}\right)=\frac{\text { Thickness }(\mathrm{m})}{\mathrm{R}-\text { Value }\left(\mathrm{M}^{2} \cdot \mathrm{K} / \mathrm{W}\right)}
$$

We can calculate density as following:

$$
\begin{aligned}
\mathrm{D} & =\frac{\mathrm{M}}{\mathrm{V}} \\
\mathrm{D} & =\text { Density }\left(\text { Kilogram } / \text { meter }^{3}\right) \\
\mathrm{M} & =\text { Mass }(\text { Kilogram }) \\
\mathrm{V} & =\text { Volume }\left(\mathrm{M}^{3}\right)
\end{aligned}
$$

\begin{tabular}{|c|c|c|c|c|}
\hline \multirow[b]{2}{*}{ Type } & \multicolumn{3}{|c|}{ Dimensions in $\mathrm{m}$} & \multirow{2}{*}{$\begin{array}{l}\text { R-Value } \\
\mathrm{M}^{2} . \mathrm{K} / \mathrm{W}\end{array}$} \\
\hline & Width & Length & Thick & \\
\hline Alu-foil Rockwool felt & 1.2 & 6.0 & $0.03-0.1$ & $1-3$ \\
\hline $\begin{array}{l}\text { Rockwool semi Rigid } \\
\text { panels }\end{array}$ & 0.6 & 1.2 & $0.03-0.1$ & $0.9-3$ \\
\hline Rockwool Rigid panels & 0.6 & 1.2 & $0.03-0.1$ & $0.9-3$ \\
\hline Rockwool Quilted matt's & 1.2 & 6.0 & $0.03-0.1$ & $1-2.7$ \\
\hline
\end{tabular}

Table 1: Materials and dimensions

Table 2: Density and K-value results

\begin{tabular}{lcl} 
Table 2: Density and K-value results \\
\hline Type & $\begin{array}{c}\text { Average density } \\
\left(\mathrm{Kg} \mathrm{m}^{-3}\right)\end{array}$ & $\begin{array}{l}\text { K-value } \\
\left(\mathrm{W} / \mathrm{M} .{ }^{\circ} \mathrm{C}\right)\end{array}$ \\
\hline Alu-foil rockwool felt & 45 & 0.030 \\
Rockwool semi rigid panels & 60 & 0.023 \\
Rockwool rigid panels & 115 & 0.033 \\
Rockwool quilted matt's & 90 & $0.030-0.036$ \\
\hline
\end{tabular}

\section{RESULTS AND DISCUSSION}

When comparing the insulation value of different types of insulation, it's important to look at the K-factor and the mean temperature. As mean temperature rises, the K-factor on some insulation materials also increase.

Insulation materials usually have K-factors less than one and are reported at what is called Mean Temperature. To determine the mean temperature, measure the surface temperatures on both sides of the insulation, add them together and divide by two.

Rockwool insulation is produced in order to minimize warmth loss and to defend against fire. Rockwool stone wool goods are classified in the new EU Fire classification system at the best classification, as Euroclass A1, non-combustible in fire. Rockwool insulation goods are made from basalt rock and slag. They are defiant to temperatures above $1000^{\circ} \mathrm{C}$ and are critical thermal and acoustic insulation goods with outstanding fire resistance characteristics.

Thermal efficiency and sustainability: Rock wool insulation equipment is one of the main environmentally welcoming and power proficient insulation goods obtainable in the marketplace today it meets the maximum principles of sustainability, power protection and recyclability. This new insulation knowledge permits users immense savings in power expenditures while taking pleasure in the maximum advantage in fire safety and nuisance diminution.

The rock wool insulation knowledge unites three rewards into one parcel that includes energy-saving, fire-safe and noise nuisance reductions. Rockwool insulation is also identified as stone wool insulation, mineral wool insulation and slag wool insulation. A broad variety of goods can be prepared from Rockwool because of its exceptional capability to obstruct sound and heat. Because of this, rock and slag wool insulation goods can considerably decrease energy use in houses, offices, businesses and production plants. This kind of insulation uses less power significantly permitting savings in houses and businesses and significantly assisting users to endure the present economic predicament. The outstanding thermal resistance of these wools is a main feature in their use as residential and commercial insulation, pipe and process insulation and a broad assortment of other functions. Additionally, the use of rock and slag wool as a horticultural growing medium has gained distinction recently.

Energy saving and reduce air pollution and global warming: The key environmental influence of Rockwool insulation is its capability to safeguard non- 
renewable fossil power and decrease air contamination as a consequence. It is one of the few industrial goods that vigorously advance the environment. A typical Rockwool product can save a hundred times more $\mathrm{CO}_{2}$, $\mathrm{SO}_{2}$ and $\mathrm{NO}_{2}$ than has been given off throughout its production. The precise environmental influence of any substance relies upon the specific good used, the plan of the overall assembly and the local weather circumstances. Life Cycle Assessments (LCAs) are a significant instrument used to certify the green profile of the goods. Over the life span of use in usual UK buildings, savings in greenhouse gases as a consequence of diminished heating are several hundred times larger than the emissions linked with producing Rockwool products. An encouraging environmental equilibrium is characteristically seen after about three weeks (Rodman and Lenssen, 1995).

The natural fundamental rock material used in creating Rockwool is a plentiful resource. Immense care is taken throughout both the production process and allocation of finished insulation goods in order to diminish any ecological forces. Rockwool's process team watches the manufacture procedure cautiously to make sure that any emission is within particular limits. It is Rockwool's policy to stick to ecological principles better than national and local necessities. The personified energy in Rockwool is almost certainly the smallest for any commercially manufactured insulation (Silver, 2008).

The environmental return of the production of a square meter of Rockwool will differ depending on its use, but will normally be around 100-300 to 1 for wall insulation systems and much higher for insulation of hot industrial pipes and procedures, usually over 10,000 to 1 . Energy saving is directly balanced to the depth of the insulation applied. One square meter of $150 \mathrm{~mm}$ loft insulation is connected with a once only cost of around 65 Mega joules of energy, but saves approximately 300 Mega joules every year.

In a comparable way, one linear meter of $50 \mathrm{~mm}$ industrial Rockwool insulation located on a larger diameter pipe with a working surface temperature of $350^{\circ} \mathrm{C}$ usually in service for half a year, will save around 57,000 Mega joules, against a one off energy cost of 67 Mega joules at installation. Rockwool insulation is one of the atypical manufacturing goods that save more power that it has to (Go).

The primary legislation controlling OzoneDepleting Substances (ODS) is the European Council Regulation on materials that have an unfavorable influence on the ozone layer in the upper atmosphere. The environmental Protection rules 2003 pertain to controls on a variety of ODSs. Rockwool insulation depends upon trapped air for its thermal characteristics, which has neither ozone depleting nor global warming possibilities.

Rockwool roll in modern green building: A key green building standard is the decrease of waste through improving building superiority and increased sturdiness. Frequently, the greenest structures are those that do not require to be replaced. Per se building goods that assist in extending the life of structures throughout more sturdy design may eradicate the need for replacement, thus reducing future downstream waste.

Because Rockwool insulation is prepared from rock that is spun into fibers, it is tremendously longlasting. When correctly put in, CSR's Rockwool insulation goods are able of upholding their original physical properties all the way through the life of the structures in which they are utilized. CSR's Rockwool insulation is also non-combustible. In reality, because the insulation fibers have melting temperatures greater than $1400-1600^{\circ} \mathrm{C}$, they are frequently used for fire prevention. Choosing CSR Rockwool over a usual fiberglass insulation product may offer the incremental advantage of fire-resistance and improved safety in structures in which they are used. CSR's Rockwool is water-resistant and permits reduced likelihood that deterioration may happen if wetness is restricted to a building's exterior. CSR's Rockwool insulation does not sustain mold, mildew or fungus, which can additionally weaken inside building fundamentals and necessitate substances replacement (Green Building, 2008).

By integrating recycled substance into building materials, green builders not only work to reduce the impact that results from the withdrawal and processing of raw resources, but also diminish the quantity of solid waste that is formed as a byproduct of the built surroundings. CSR's Rockwool insulation goods include an average of $7.5 \%$ post-industrial recycled substance.

Good interior air quality improves inhabitant's wellbeing and comfort and is a necessary objective for any green building. The U.S. Environmental Protection Agency estimates that interior pollution amounts may be two to five times greater than outside pollution amounts. Potential pressures to interior environmental excellence comprise the incidence of hazardous chemicals, high concentrations of fivers in the air and smoke, mildew, mold and fungus pollution. Rockwool includes no asbestos or chemical additives. Neither the raw substance used in production nor the finished product have any ozone reducing chemicals. In addition, CSR's Rockwool insulation goods are not categorized as, nor do they have, hazardous air contaminants. While phenol-formaldehyde is present in 
the production process, features of the method itself, such as high temperature heat curing and intrinsic chemical reactions, do away with all free formaldehyde from the final insulation product.

CSR's Rockwool insulation goods meet four major principles used in green building initiatives. By way of it its water repellent temperament, heat resistant and non-combustible material characteristics, Rockwool insulation can advance building stability. In addition, Rockwool insulation may be efficiently used to make the most of energy efficiency and reducing heat and cooling loss, as a function of its low thermalconductivity. CSR's Rockwool goods contain $7.5 \%$ preconsumer recycled material, on average, contain no free formaldehyde and may have pollutant levels which fall below U.S. EPA, OSHA and LEED standards, thus being potentially useful in enhancing indoor air quality (Green Building, 2008; Silver, 2008).

Green and sustainable building agendas are beginning to have great influence on the selection of materials being used in structures. One technique, used by the US Green Building Council (USGBC) to encourage green and sustainable structures, is a scoring system called Leadership in Energy and Environmental Design (LEED ${ }^{\mathrm{TM}}$ ). LEED assigns points to a structure that meets exact objectives and exact point amounts establish the building's LEED rating. Rock and slag wool goods can aid green building developers earn points in the direction of a LEED rating, particularly in the area of materials and resources where clpoints are earned for recycled substance and regional material substance. In utilizing these point-based structures, though, it is easy to overlook that the central purposes of insulation is to save energy and advance comfort, which are core supports of sustainable building. Consequently, all insulation is theoretically green. What is more important than just points in choosing an insulation substance is its appropriateness for the plan based on the amount of environmental criteria and requirement of appropriate amounts of insulation for the function, which are usually ahead of the minimum commanded by rules. Rock and slag wool insulations symbolize a number of properties that make them beneficial options in green and sustainable construction (Green Building, 2008; Straube, 2007).

\section{CONCLUSION}

The most sustainable energy is saved energy. Rockwool insulation products are thought to be the most sustainable solution for a good amount of reasons:

- The use of many natural and renewable raw materials in producing Rockwool insulation
- Rockwool insulation's one of a kind fire-retardant

- The unique trait of durability externally and biosolubility

- No hazardous classifications

- The reality that Rockwool uses no raw materials nor contains any substances that are carcinogenic, mutagenic or toxic to reproduction

- Even when no longer in use, Rockwool insulation can be recycled when a building is deconstructed at the end of its life

\section{REFERENCES}

Fisk, W. and A. Rosenfeld, 1998. Potential nation wide improvement in productivity and health form better indoor environments. Proceedings of the Summer Study on Energy Efficiency in Buildings Energy Efficeieny in a competitive Enviornment Amaerican Council for an Energy Efficient Economy, Aug. 23-28, Asilomare, CA., pp: 8.85-8.97.

Green Building, 2008. CSR Building Materials Rockwool Insulation. Green Building.com. http://www.green-buildings.com/content/781270csr-building-materials-rockwool-insulation

Krigger, j., C. Dorsi, 2004. Residential Energy. FAQs about Mineral Wool. Saturn Resource Mangement. http://srmi.biz/Bookstore.Professionals.Residential _Energy.htm

Kudo, Y., M. Kotani, M. Tomita and Y. Aizawa, 2009. Effects of rock wool on the lungs evaluated by magnetometry and biopersistence test. J. Occup. Med. Toxicol., 4: 5. DOI: 10.1186/1745-6673-4-5

Rodman, D.M. and N. K. Lenssen, 1995. A building Revolution. Ist Edn. Worldwatch Institute, Washington, ISBN: 1878071254, pp: 67.

Silver, J., 2008. Global Warming Demystified. Ist Edn. McGraw-Hill, New York, ISBN: 0071502408, pp: 289.

Straube, J., 2007. Building Science Digests: BSD-011: Thermal Control in Buildings. Building Science Corporation. http://www.buildingscience.com/documents/digest s/bsd-011-thermal-control-in-buildings 